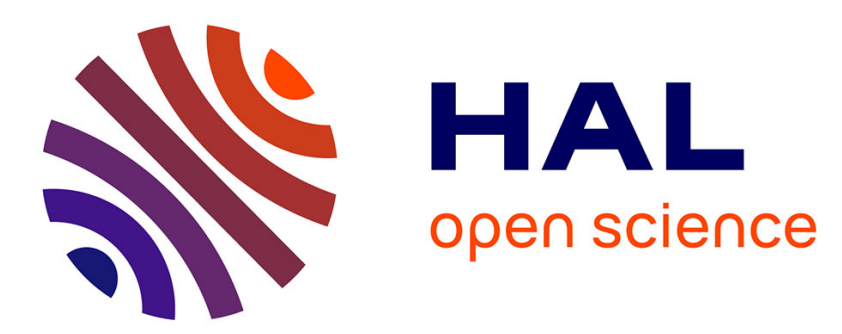

\title{
Absence of isolation by distance patterns at the regional scale in the fungal plant pathogen Leptosphaeria maculans
}

Renaud Travadon, Ivan Sache, Christian Cyril Dutech, Anna Stachowiak, Bruno Marquer, Lydia Bousset

\section{To cite this version:}

Renaud Travadon, Ivan Sache, Christian Cyril Dutech, Anna Stachowiak, Bruno Marquer, et al.. Absence of isolation by distance patterns at the regional scale in the fungal plant pathogen Leptosphaeria maculans. Fungal Biology, 2011, 115 (7), pp.649-659. 10.1016/j.funbio.2011.03.009 . hal-01189592

\section{HAL Id: hal-01189592 \\ https://hal.science/hal-01189592}

Submitted on 29 May 2020

HAL is a multi-disciplinary open access archive for the deposit and dissemination of scientific research documents, whether they are published or not. The documents may come from teaching and research institutions in France or abroad, or from public or private research centers.
L'archive ouverte pluridisciplinaire HAL, est destinée au dépôt et à la diffusion de documents scientifiques de niveau recherche, publiés ou non, émanant des établissements d'enseignement et de recherche français ou étrangers, des laboratoires publics ou privés. 


\title{
Absence of isolation by distance patterns at the regional scale in the fungal plant pathogen Leptosphaeria maculans
}

\author{
Renaud TRAVADON ${ }^{\mathrm{a}}$, Ivan SACHE ${ }^{\mathrm{b}}$, Cyril DUTECH $^{\mathrm{c}}$, Anna STACHOWIAK $^{\mathrm{b}, \mathrm{d}}$, \\ Bruno MARQUER $^{\mathrm{a}}$, Lydia BOUSSET ${ }^{\mathrm{a}}$
}

aINRA, AgroCampus Ouest, UMR1099 BiO3P, 35653 Le Rheu, France

bINRA, UR1290 BIOGER-CPP, Campus AgroParisTech, 78850 Thiverval-Grignon, France

'INRA, UMR1202 BIOGECO,_Equipe de Pathologie Foresti_ere, 33612 Cestas, France

${ }^{\mathrm{d} I n s t i t u t e}$ of Plant Genetics, Polish Academy of Sciences, Strzeszynska 34, PL-60479 Poznan, Poland

\begin{abstract}
Outcomes of host-pathogen coevolution are influenced by migration rates of the interacting species. Reduced gene flow with increasing spatial distance between populations leads to spatial genetic structure, as predicted by the isolation by distance (IBD) model. In wind-dispersed plant-pathogenic fungi, a significant spatial genetic structure is theoretically expected if local spore dispersal is more frequent than long-distance dispersal, but this remains to be documented by empirical data. For 29 populations of the oilseed rape fungus Leptosphaeria maculans sampled from two French regions, genetic structure was determined using eight minisatellite markers. Gene diversity $(H=0.62-0.70)$ and haplotypic richness $(R=0.96-1)$ were high in all populations. No linkage disequilibrium was detected between loci, suggesting the prevalence of panmictic sexual reproduction. Analysis of molecular variance showed that $>97 \%$ of genetic diversity was observed within populations. Genetic differentiation was low among populations $\left(F_{\mathrm{st}}<0.05\right)$. Although direct methods previously revealed short-distance dispersal for $L$. maculans, our findings of no correlation between genetic and geographic distances among populations illustrate that the IBD model does not account for dispersal of the fungus at the spatial scale we examined. These results indicate high gene flow among French populations of $L$. maculans, suggesting high dispersal rates and/or large effective population sizes, two characteristics giving the pathogen high evolutionary potential against the deployment of resistant oilseed rape cultivars.
\end{abstract}

Keywords: Gene flow, Indirect measures, Minisatellites, Spatial genetic structure, Spore dispersal

\section{Highlights}

- We investigate the spatial genetic structure of Leptosphaeria maculans in France.

- We test the relevance of the isolation by distance model to describe spore dispersal.

- We found no correlation between genetic and geographic distances among populations.

- Results indicate high gene flow among populations.

- High dispersal rates and large effective population sizes characterize L. maculans.

\section{Introduction}

Dispersal has an important influence on patterns of local adaptation of plant pathogens to their host (Kaltz \& Shykoff 1998), especially in agricultural ecosystems where migration of virulent pathogen genotypes is favoured compared to immobile, cultivated resistant host genotypes. These unbalanced migration rates between host plants and pathogens eventually lead to a reduced efficacy of plant resistance (Gandon et al. 1996). Durable disease control, therefore, requires the deployment of resistant varieties in a spatial arrangement that limits disease transmission (Aubertot et al. 2006). The spatial scale of relevance for such an arrangement should match the scale of gene flow between pathogen populations. For wind-dispersed, plantpathogenic fungi, spore dispersal usually occurs both at long distances over hundreds of kilometres (lowfrequency, atmospheric dispersal) and at short distances within a few hundred metres (high-frequency, local dispersal) (Aylor \& Irwin 1999). Locally, the number of deposited spores decreases with increasing distance from the inoculum source (Gregory 1973). Spore trapping experiments, however, do not always yield consistent estimates at increasing distances from the inoculum source, thereby underestimating rare events of long-distance dispersal (McCartney et al. 2006). 
When direct measures fail, the scale of spore dispersal can be inferred from indirect genetic measures. If local dispersal is predominant, the resulting pattern of neutral genetic differentiation between populations is expected to follow the 'isolation by distance' (IBD) model (Wright, 1943, Slatkin, 1987; Rousset 1997). Assuming that neutral genetic structure is primarily due to genetic drift and is counterbalanced by gene dispersal (in a two-dimensional environment), and that it reflects the dispersal capacities of the studied species, a linear correlation is expected between the logarithm of the geographical distance and

estimated between pairs of populations ( $F_{\text {st }}$ being the index of genetic differentiation among populations; Wright 1943). The detection of an IBD pattern requires a precise framework, assuming mutationdrift equilibrium, and considering spatial distances ranging between $\sigma$ and $20 \sigma$, where $\sigma^{2}$ is the second moment of parent-offspring distance dispersal (Rousset 1997). Estimations through this method have been shown to be robust to the mutational process of microsatellite loci (i.e. allele size homoplasy), and to spatial and temporal heterogeneities of demographic parameters (i.e. variation in dispersal and density) (Leblois et al. 2003, 2004). Furthermore, analysis conducted at a local scale allows reducing the influence of selection pressure on genetic differentiation (Rousset 2001). For several tropical tree species, indirect gene dispersal estimates were consistent with direct estimates of seed and pollen dispersal (Hardy et al. 2006).

Among wind-dispersed fungi, IBD patterns have been tested at inter-continental scales, at which the spatial genetic structure could either reflect past, stochastic, and rare long-distance colonisation events (Linde et al. 2002; Rivas et al. 2004; Zaffarano et al. 2006), or the presence of physical barriers to gene flow (mountains, seas, and deserts) (Hayden et al. 2007). At broad spatial scales, the effects of selection, mutation, and demographic variation on genetic differentiation are not negligible; thus, translating measures of genetic differentiation such as $F_{\text {st }}$ and related indices into a quantitative evaluation of spore dispersal when transformed as a direct measure of the product of effective population size and number of successful migrants per generation, could often lead to misinterpretation (see for example Whitlock \& McCauley 1999). One way to test for the relevance of the IBD model to plant-pathogenic fungi when $\sigma$ is not known is to compare spatial scales. For instance, in populations of the poplar rust fungus Melampsora larici-populina, Barrès et al. (2008) detected IBD patterns within Europe, but population genetic structures from Iceland and Canada were shown to result from rare long-distance dispersal events.

Leptosphaeria maculans (Desm.) Ces. \& de Not. (anamorph Phoma lingam Tode ex Fr.), is a heterothallic, haploid fungus causing Phoma stem canker, a disease responsible of severe yield losses of Brassica, especially oilseed rape (Brassicanapus) world-wide (Fitt et al. 2006). In French oilseed rape crops, the life-cycle of the fungus matches the host presence, which is from Sep. to Jun. A single, sexual reproduction cycle per year occurs during summer on infected stubble (Fitt et al. 2006). While the resulting ascospores were once thought to travel on distances up to $10 \mathrm{~km}$ (McGee 1977), direct measures recently suggested that most ascospores were indeed concentrated within a few hundred metres from the previous year's crop (Salam et al., 2001, Marcroft et al., 2004). From previous indirect measures, contradictory conclusions were drawn on the dispersal abilities of L. maculans. At the inter-continental scale, Amplified Fragment Length Polymorphism (AFLP) analysis differentiated Australian, North American, and European L. maculans populations (Purwantara et al. 2000). In Australia, AFLP and Restriction Fragment Length Polymorphism markers did not reveal a genetic east-west differentiation among populations (Barrins et al. 2004), a differentiation which was subsequently revealed by microsatellite and minisatellite markers (Hayden et al. 2007), and explained as a result of the separation of these two regions by an arid desert. In Canada, Random Amplified Polymorphic DNA markers differentiated two populations sampled from $20 \mathrm{~km}$ distant fields (Mahuku et al. 1997). In contrast, a study conducted in France, including four minisatellite markers used in the present study, showed low genetic differentiation among L. maculans populations (Gout et al. 2006). Findings of Gout et al. (2006) are based on only four populations with a scatter distribution across France. This sampling was not designed to infer spore dispersal parameters through indirect genetic measures, but rather allowed the examination of levels and distribution of within-population genetic diversity. The low measures of genetic differentiation reported by Gout et al. (2006), who estimated that $>99.5 \%$ of genetic diversity measured at four minisatellite markers was present within two square metres field plots, do not allow the assessment of the minor variation in genetic differentiation within a local spatial scale, which could possibly reflect the evolution of $L$. maculans populations under an IBD model. 
The aim of the present study was to test the relevance of the IBD model to a windborne plantpathogenic fungus. Indeed, it remains to be proven that IBD patterns can be detected in agricultural ecosystems characterized by pathogen populations with a high multiplication rate, a large population size alternating with recurrent yearly bottlenecks, or with a recent range expansion. Based on a priori knowledge of the organism's dispersal abilities, the genetic structure of $L$. maculans was investigated at a spatial scale where gene flow was expected to occur. Direct measures of ascospore dispersal distances suggest that $L$. maculans populations separated by geographic distances ranging from several hundred metres to $10 \mathrm{~km}$ evolve under IBD (Salam et al., 2001, Marcroft et al., 2004). We developed four new minisatellite markers and genotyped 693 isolates at eight loci. We sampled 29 field populations in two regions of France, covering distances ranging from a few hundred metres to one hundred kilometres in each region. Our objective was to test for the presence of IBD pattern in the genetic structure of $L$. maculans populations. Also, we tested whether the detection of IBD pattern was not erased by a recent range expansion of the pathogen. To this aim, we compared pathogen genetic structure in Region Brittany, where the cultivation of B. napus - and thus the presence of its $L$. maculans pathogen - is less than 25-y-old, with that of Region Centre, where oilseed rape has been intensively cultivated for more than $60 \mathrm{y}$.

\section{Materials and methods}

Sample collection and DNA extraction

In autumn 2004 and 2005, 693 isolates were collected from 29 commercial oilseed rape fields in two regions [western France (Region Brittany, $n=17$ ) and central France (Region Centre, $n=12$ ) (Fig 1)]. In 2007, 66405 ha of oilseed rape were grown in the Department Cher (Region Centre), compared to only 12950 ha in the Department Ille-et-Vilaine (Region Brittany) (Prolea 2008). Pair-wise distances between field populations ranged from $0.44 \mathrm{~km}$ to $364 \mathrm{~km}$ (from $0.44 \mathrm{~km}$ to $99.7 \mathrm{~km}$ and from $1.32 \mathrm{~km}$ to $114.5 \mathrm{~km}$ in Region Brittany and in Region Centre, respectively). In each field, one infected leaf displaying typical phoma leaf spots was collected from each of 23-25 plants. Monospore mycelial cultures were increased on V8 juice agar at $20{ }^{\circ} \mathrm{C}$ for $21 \mathrm{~d}$ (Chèvre et al. 2008), then scraped with a sterile scalpel. DNA was extracted from lyophilized mycelia following the standard protocol supplied in the Nucleospin ${ }^{\circledR}$ Plant II kit (Macherey-Nagel, Düren, Germany).

Fig 1. Map of France showing the location of the 29 French field populations sampled (0) in Regions Brittany and Centre. The main towns in the sampling areas are marked with $a \times$ on the map.

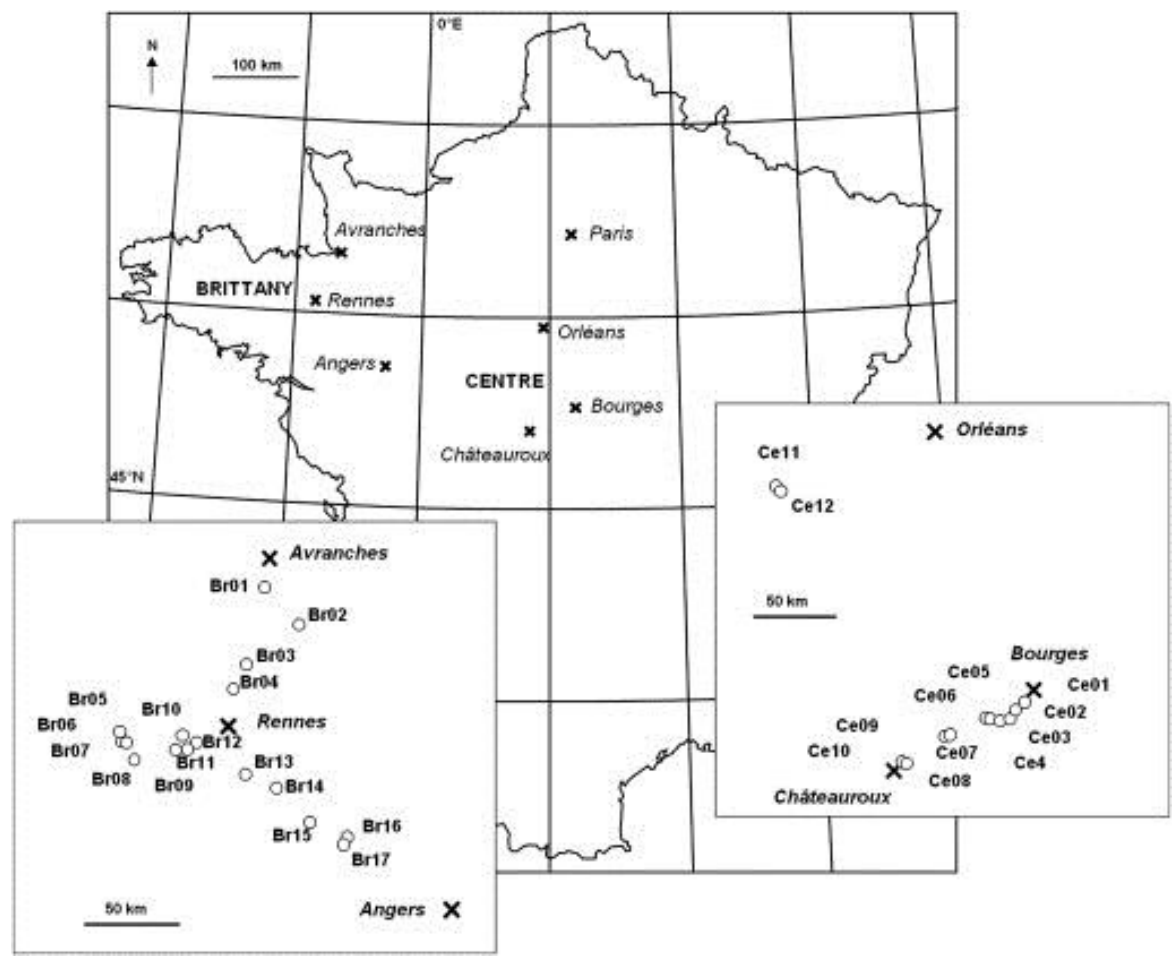


Minisatellite identification

A systematic search approach described by Eckert et al. (2005) was undertaken in order to identify minisatellite loci in Leptosphaeria maculans. BAC-end sequence data, from the v23.1.3 genomic DNA HindIII BAC library (Attard et al. 2002), were screened for regions with tandem repeat using TANDEM REPEAT FINDER (Benson 1999). Primers were designed using Oligo6 (MedProbe, Norway). Genomic DNA of 56 isolates was extracted, comprising 50 L. maculans 'brassicae', one L. maculans 'lepidii' (IBCN84), as well as one Leptosphaeria biglobosa 'brassicae' (IBCN93), 'thlaspii' (IBCN65), 'canadensis' (IBCN82), 'australensis' (IBCN91), and 'erysimii' (IBCN83). These isolates were obtained from existing collections maintained at INRA Versailles, and previously described (Gall et al. 1994; Balesdent et al., 2001, MendesPereira et al., 2003). In order to analyse the genetic control of minisatellite segregation, progeny from in vitro cross a. 2 × H5 (Balesdent et al. 2001) was used. TANDEM REPEAT FINDER highlighted 203 out of 2550 BAC-end sequences analysed as sequences with putative tandem repeats, for which primer pairs specific to flanking regions of tandem repeats were designed. These primer pairs were first tested on genomic DNA from a set of $7 \mathrm{~L}$. maculans 'brassicae' isolates originating from diverse geographical locations. This first screen resulted in 23 primer pairs generating polymorphic products (2-4 variants of alleles). Then, these 23 primer pairs were tested on $47 \mathrm{~L}$. maculans isolates of diverse geographical origin. Moreover, 12 of them displayed polymorphism between a. 2 and H5 parental isolates. Meiotic segregation of minisatellite markers confirmed that these 12 new markers were single-locus sequences. Among these 12 markers, four were chosen according both to their polymorphism, and to their specificity to L. maculans.

\section{Minisatellite amplification}

Multilocus genotypes were characterized with minisatellite loci MinLm2, MinLm4, MinLm5, MinLm6 (Eckert et al. 2005), and MinLm8, MinLm9, MinLm632, MinLm1377 for which primers were designed (Table 1). Forward primers were fluorescently-labelled. PCR reactions were performed in a $20-\mu l$ final volume containing 10-30 ng of genomic DNA, $1 \times$ PCR buffer, $200 \mu \mathrm{M}$ of each dNTPs, $1.5 \mathrm{mM} \mathrm{MgCl}_{2}$, each primer at $0.5 \mu \mathrm{M}, 0.25 \mathrm{U} \mathrm{GoTaq}^{\circledR}$ DNA Polymerase (Promega, WI, USA). Amplifications were carried out in a GSTORM GS4 thermocycler (GRI Ltd., Braintree, UK) using one cycle of $94{ }^{\circ} \mathrm{C}$ for $4 \mathrm{~min}$, followed by 30 cycles of $94{ }^{\circ} \mathrm{C}$ for $30 \mathrm{~s}$, annealing temperature for $30 \mathrm{~s}$ (Table 1), $72{ }^{\circ} \mathrm{C}$ for $1 \mathrm{~min}$, and $5 \mathrm{~min}$ of final extension at $72{ }^{\circ} \mathrm{C}$. Allele assignments were performed on an ABI PRISM ${ }^{\circledR} 3130 x 1$ sequencer using manufacturer's instructions with the GENEMAPPER 3.7 software (Applied Biosystems).

Table 1. Minisatellite markers and PCR primers used to characterise molecular diversity in populations of Leptosphaeria maculans sampled in two regions of France.

\begin{tabular}{|c|c|c|c|c|c|c|}
\hline Minisatellite & $\begin{array}{l}\text { Accession } \\
\text { number }^{b}\end{array}$ & Minisatellite consensus $\left(5^{\prime}-3^{\prime}\right)$ & $\begin{array}{l}\text { Consensus } \\
\text { length (bp) }\end{array}$ & $\begin{array}{l}\text { Primer } \\
\text { name }\end{array}$ & Primer sequence $\left(5^{\prime}-3^{\prime}\right)$ & $\begin{array}{c}\text { Annealing } \\
\text { temperature }\left({ }^{\circ} \mathrm{C}\right)\end{array}$ \\
\hline $\operatorname{MinLm} 2^{\mathrm{a}}$ & AJ294758 & GAGACATGGGAAATAGAGGAGGAA & 24 & $\begin{array}{l}\operatorname{MinLm} 2 F \\
\operatorname{MinLm} 2 R\end{array}$ & $\begin{array}{l}\text { AAGAAGGTGGGTGGATTGGTAAG } \\
\text { GCCCTCTTTTCCTCGTTGC }\end{array}$ & 60 \\
\hline $\operatorname{MinL} m 4^{\mathrm{a}}$ & AJ621803 & ACAACTTCAATCCGCCTGCTGATTATCCCTATACATATCAGACCAAGCAAG & 51 & $\begin{array}{l}\text { MinLm4F } \\
\text { MinLm4R }\end{array}$ & $\begin{array}{l}\text { ACCAGGTGGAGTTGATAACAT } \\
\text { TCCTGCGAATCCCATTAG }\end{array}$ & 53 \\
\hline $\operatorname{MinL} m 5^{\mathrm{a}}$ & AJ621804 & ACCGCCCAGCCACTCA & 16 & $\begin{array}{l}\text { MinLm5-ULG } \\
\text { MinLm5-LLG }\end{array}$ & $\begin{array}{l}\text { GCCGCCCGCCGCCTTACC } \\
\text { GAGCTCCTGCGCCACAGTG }\end{array}$ & 60 \\
\hline $\operatorname{MinLm} 6^{\mathrm{a}}$ & AJ621805 & GGCAGGGCTGGCCATGGGGA & 21 & $\begin{array}{l}\text { MinLm6F } \\
\text { MinLm6R }\end{array}$ & $\begin{array}{l}\text { GGAAGGAACACACGGTGAC } \\
\text { AATTGAATGATTTGCGACACA }\end{array}$ & 53 \\
\hline MinLm8 & HQ637176 & TGTATATACAGTACAAAGACACACACA & 27 & $\begin{array}{l}\text { MinLm8F } \\
\text { MinLm8R }\end{array}$ & $\begin{array}{l}\text { ATTTGCTGGCGGTGTAGGTA } \\
\text { TGTTTGTACATGTGGTAAGTAAAGCA }\end{array}$ & 53 \\
\hline $\operatorname{Min} L m 9$ & HQ604861 & GTGTGTGTGTGCGTGTGT & 18 & $\begin{array}{l}\text { MinLm9F } \\
\text { MinLm9R }\end{array}$ & $\begin{array}{l}\text { GCATTTGTTGGCTGGCATTGGA } \\
\text { TGCGTTGGCGTGTGACATGACT }\end{array}$ & 60 \\
\hline MinLm632 & HQ604859 & СTCTGTCTTTCTCTTTCTCTCTCTCTGT & 28 & $\begin{array}{l}\text { MinLm632F } \\
\text { MinLm632R }\end{array}$ & $\begin{array}{l}\text { TCAGACGCTGCTGGCCTGTGTG } \\
\text { AGTGAGCCGACGAGACGCGAGAG }\end{array}$ & 64 \\
\hline MinLm1377 & HQ604860 & TTGTCGGATGTCCCCTGTCCTGTCTTGTGCTGTGTC & 36 & $\begin{array}{l}\text { MinLm1377F } \\
\text { MinLm1377R }\end{array}$ & $\begin{array}{l}\text { CGTCCAGTCGTGCCTGCCTTTG } \\
\text { GGTGCATGTCTTGGCGGACCATT }\end{array}$ & 64 \\
\hline
\end{tabular}

${ }^{\text {a }}$ Eckert et al. 2005.

${ }^{\mathrm{b}}$ GenBank database accession number. 
Data analysis

Multilocus haplotypes were constructed for each isolate. All isolates collected within the same field were considered as one population. We determined the number of identical multilocus haplotypes within and across populations, using GENCLONE 2.0 (Arnaud-Haond \& Belkhir 2007). The same program was used to estimate the probability that identical multilocus haplotypes were the result of a distinct sexual reproductive event $\left(P_{\text {sex }}\right)$, rather than clonal spread, based on the number of loci and allelic frequencies. For each locus within each population, mean number of alleles $\left(N_{\text {all }}\right)$, Nei's gene diversity corrected for sample size $(h)($ Nei 1987$)$ and allele frequencies were estimated using SPAGEDI 1.2 (Hardy \& Vekemans 2002). At a given locus, Nei's gene diversity $(h)$ is defined as the probability that two sampled alleles are different. Mean gene diversity $(H)$ was calculated as the mean of $h$ across loci within each population. In each population, haplotypic richness $(R)$ was estimated as $R=(G-1) /(N-1)$, where $G$ is the number of unique haplotypes and $N$ is the number of isolates (Dorken \& Eckert 2001).

For each pair of loci within each population, gametic linkage disequilibria were computed using GENEPOP 4.0 (Raymond \& Rousset 1995). The index of multilocus linkage disequilibrium $r_{d}$ (Agapow \& Burt 2001) was computed for each population. The significance of $r_{d}$, which is expected to equal zero if there is no linkage disequilibrium, was tested by comparing the observed variance with the distribution of the variance expected under the null hypothesis of random mating, as determined from 1000 randomizations of the haplotype data implemented in MULTILOCUS 1.3 (Agapow \& Burt 2001).

For each locus and across all populations, Nei's estimator of genetic differentiation $\left(G_{\mathrm{ST}}\right)$ was calculated with FSTAT 2.9.3 (Goudet 1995). $G_{\text {ST }}$ indicates the proportion of the total genetic variation attributable to population differentiation. Values close to zero indicate little differentiation while values close to unity indicate nearly complete differentiation. The null hypothesis of no genetic differentiation between field populations was also tested using FSTAT to estimate $\theta$ (Weir \& Cockerham 1984), an unbiased estimator of the parameter $F_{\text {st. }}$ Significance levels were determined after Bonferroni corrections based on the adjusted $P$-value following 8000 permutations. Genetic differentiation was estimated with a hierarchical analysis of molecular variance (AMOVA) using ARLEQUIN 3.1 (Excoffier et al. 2005). AMOVA was used to determine the proportion of genetic variation partitioned among the two regions, among fields within a region, or among individuals within a field. The number of permutations to test for significance was set at 5000 .

IBD between populations was tested using the method described by Rousset (1997), under which a correlation is expected between the logarithm of the geographical distance and the genetic distance $\theta /(1-\theta)$, assuming gene flow in a two-dimensional environment. Data analysis involves the regression of $F_{\mathrm{ST}} /\left(1-F_{\mathrm{ST}}\right)$ estimates for each pair of subpopulations. Pair-wise geographical distances among field populations were calculated without correcting for the Earth's curvature because of the limited spatial distance among fields. Significance was tested using a Mantel test (1000 permutations) implemented in GENEPOP.

A test to detect evidence of recent demographic fluctuations was performed with BOTTLENECK (Piry et al. 1999). For each population and for each locus, we estimated gene diversity as expected under the assumption of mutation-drift equilibrium (expected gene diversity), from the number of alleles and sample size, and compared it to gene diversity calculated directly from the allele frequencies $\left(H_{\text {obs}}\right.$, observed gene diversity). In a population that has undergone a bottleneck, gene diversity is higher than expected at equilibrium, due to a high-frequency of rare alleles (Cornuet \& Luikart 1996). Gene diversity was estimated under three mutation models: the infinite allele model (IAM), the stepwise mutation model (SMM), and the two-phase model (TPM) (Rienzo et al. 1994). In the IAM, each mutation creates a novel allele at constant rate. In the SMM, each mutation creates a novel allele by adding or deleting a single repeated unit of the minisatellite. TPM is an offshoot of SMM developed to account for a proportion of larger mutation events (addition or deletion of several units). We tested these three mutation models because patterns of mutation for minisatellites are not perfectly known and can vary from one locus to another. The proportion of alleles attributed to SMM under TPM was $70 \%$, with a variance of 30 (default parameters). Estimations were based on 1000 replications. The Wilcoxon sign-rank test (Luikart et al. 1997) was performed to determine if the allele frequency distribution deviates significantly from that expected under mutation-drift equilibrium. 


\section{Results}

Genetic diversity within populations

Across all 29 populations, the number of alleles at each locus ranged from 3 (MinLm4) to 21 (MinLm632), and only one locus (MinLm4) presented one allele occurring at a frequency greater than $95 \%$. Average gene diversity across populations ranged from 0.05 (MinLm4) to 0.87 (MinLm2) (Table 2). Mean number of alleles per locus $\left(N_{\text {all }}\right)$ was $5.88( \pm 0.45$, standard deviation), ranging from 4.88 to 7 in the Ce11 (Region Centre) and Br14 (Region Brittany) field populations, respectively. Mean gene diversity $H$ across all loci was high $(0.66 \pm 0.02)$ and homogeneous (Table 3$)$. Among all 693 isolates analysed, 687 multilocus haplotypes were obtained. Isolates sharing identical multilocus haplotypes were recovered from the same population (Br06, $\mathrm{Ce} 08$, and Br16) and likely resulted from clonal spread, as the probability that these repeated multilocus haplotypes originated from distinct sexual reproduction events was low $\left(P_{\mathrm{sex}}<0.005\right)$. In contrast, isolates sharing identical multilocus haplotypes were identified from different populations in the same region (Br16Br06, Br04-Br13) or from different populations in different regions (Ce10-Br15) and likely resulted from distinct sexual reproduction events $\left(P_{\mathrm{sex}}>0.096\right)$. Numbers of haplotypes equalled numbers of isolates in 26 field populations (Table 3), and haplotypic richness $(R)$ was high in all field populations $(0.96-1)$.

Table 2. Frequency of the most common (frequency greater than 0.05) minisatellite alleles, gene diversity (h), number of alleles at the eight minisatellite loci, and Nei's estimator of genetic differentiation $\left(\mathrm{G}_{S T}\right)$ per locus across the 29 field populations of Leptosphaeria maculans.

\begin{tabular}{|c|c|c|c|c|c|}
\hline Minisatellite & Allele $^{\mathrm{a}}$ & Allele frequency & $h$ (gene diversity) & Number of alleles & $G_{S T}^{b}$ \\
\hline \multirow[t]{4}{*}{ MinLm2 } & $6 \mathrm{X}$ & 0.23 & 0.87 & 20 & 0.001 \\
\hline & $7 X$ & 0.15 & & & \\
\hline & $8 \mathrm{X}$ & 0.07 & & & \\
\hline & $9 \mathrm{X}$ & 0.19 & & & \\
\hline MinLm4 & $3 x$ & 0.97 & 0.05 & 3 & -0.008 \\
\hline \multirow[t]{2}{*}{$\operatorname{MinLm5}$} & $7 X$ & 0.55 & 0.58 & 6 & -0.01 \\
\hline & $8 \mathrm{x}$ & 0.34 & & & \\
\hline \multirow[t]{4}{*}{$\operatorname{MinLm6}$} & $3 x$ & 0.11 & 0.65 & 8 & 0.009 \\
\hline & $4 X$ & 0.44 & & & \\
\hline & $5 X$ & 0.37 & & & \\
\hline & $6 \mathrm{X}$ & 0.06 & & & \\
\hline \multirow[t]{4}{*}{$\operatorname{Min} \operatorname{L} m 8$} & $5 X$ & 0.13 & 0.77 & 14 & 0.008 \\
\hline & $6 \mathrm{X}$ & 0.26 & & & \\
\hline & $7 \mathrm{X}$ & 0.36 & & & \\
\hline & $8 \mathrm{X}$ & 0.14 & & & \\
\hline \multirow[t]{7}{*}{$\operatorname{Min} \operatorname{Lm} 9$} & $3 x$ & 0.14 & 0.85 & 17 & -0.001 \\
\hline & $5 X$ & 0.13 & & & \\
\hline & $6 \mathrm{X}$ & 0.16 & & & \\
\hline & $7 X$ & 0.05 & & & \\
\hline & $9 \mathrm{X}$ & 0.26 & & & \\
\hline & $10 \mathrm{X}$ & 0.07 & & & \\
\hline & $11 x$ & 0.11 & & & \\
\hline \multirow[t]{4}{*}{$\operatorname{Min} L m 632$} & $4 \mathrm{X}$ & 0.15 & 0.77 & 21 & 0.008 \\
\hline & $7 X$ & 0.41 & & & \\
\hline & $8 \mathrm{X}$ & 0.10 & & & \\
\hline & $18 \mathrm{X}$ & 0.15 & & & \\
\hline \multirow[t]{5}{*}{$\operatorname{MinLm1377}$} & $4 \mathrm{X}$ & 0.11 & 0.84 & 13 & 0.003 \\
\hline & $5 X$ & 0.20 & & & \\
\hline & $6 \mathrm{X}$ & 0.28 & & & \\
\hline & $7 X$ & 0.14 & & & \\
\hline & $8 \mathrm{X}$ & 0.08 & & & \\
\hline
\end{tabular}


Table 3. Field population code, number of analysed isolates $(\mathrm{N})$, number of observed haplotypes $(\mathrm{G})$, haplotypic richness $(\mathrm{R})$, mean number of alleles over the eight loci $\left(\mathrm{N}_{\text {all }}\right)$, mean gene diversity over the eight loci $(\mathrm{H})$ and index of multilocus linkage disequilibrium $\left(\mathrm{r}_{\mathrm{d}}\right)$.

\begin{tabular}{|c|c|c|c|c|c|c|}
\hline Population $^{a}$ & $N$ & G & $\mathrm{R}$ & $\mathrm{N}_{\text {all }}$ & $\mathrm{H}$ & $r_{d}$ \\
\hline $\mathrm{Br} 01$ & 24 & 24 & 1 & 6.38 & 0.69 & -0.019 \\
\hline $\mathrm{BrO} 2$ & 23 & 23 & 1 & 5.75 & 0.66 & -0.037 \\
\hline $\mathrm{BrO3}$ & 24 & 24 & 1 & 5.88 & 0.64 & 0.008 \\
\hline $\mathrm{BrO4}$ & 24 & 24 & 1 & 5.88 & 0.64 & -0.004 \\
\hline $\mathrm{Br} 05$ & 24 & 24 & 1 & 5.63 & 0.65 & -0.004 \\
\hline $\mathrm{Br} 06$ & 24 & 23 & 0.96 & 6.00 & 0.66 & 0.041 \\
\hline $\mathrm{Br} 07$ & 24 & 24 & 1 & 6.25 & 0.70 & -0.019 \\
\hline $\mathrm{Br} 08$ & 23 & 23 & 1 & 5.25 & 0.65 & -0.018 \\
\hline $\mathrm{BrO9}$ & 23 & 23 & 1 & 5.75 & 0.66 & 0.009 \\
\hline $\mathrm{Br} 10$ & 24 & 24 & 1 & 5.88 & 0.65 & -0.002 \\
\hline $\mathrm{Br} 11$ & 25 & 25 & 1 & 5.88 & 0.66 & -0.011 \\
\hline $\mathrm{Br} 12$ & 24 & 24 & 1 & 5.00 & 0.62 & 0.003 \\
\hline $\mathrm{Br} 13$ & 24 & 24 & 1 & 6.00 & 0.65 & $<0.001$ \\
\hline Br14 & 24 & 24 & 1 & 7.00 & 0.67 & 0.001 \\
\hline $\mathrm{Br} 15$ & 24 & 24 & 1 & 5.88 & 0.66 & -0.014 \\
\hline Br16 & 24 & 23 & 0.96 & 5.63 & 0.65 & 0.028 \\
\hline $\mathrm{Br} 17$ & 24 & 24 & 1 & 5.50 & 0.67 & 0.008 \\
\hline $\mathrm{Ce} 01$ & 24 & 24 & 1 & 6.13 & 0.69 & 0.013 \\
\hline $\mathrm{Ce} 02$ & 23 & 23 & 1 & 6.63 & 0.68 & -0.015 \\
\hline $\mathrm{Ce} 03$ & 24 & 24 & 1 & 5.63 & 0.64 & 0.016 \\
\hline $\mathrm{Ce} 04$ & 24 & 24 & 1 & 6.63 & 0.67 & 0.038 \\
\hline $\mathrm{Ce} 05$ & 24 & 24 & 1 & 6.00 & 0.64 & -0.020 \\
\hline $\mathrm{Ce} 06$ & 24 & 24 & 1 & 6.13 & 0.69 & -0.008 \\
\hline $\mathrm{Ce} 07$ & 24 & 24 & 1 & 6.13 & 0.66 & 0.018 \\
\hline $\mathrm{Ce} 08$ & 24 & 23 & 0.96 & 5.63 & 0.62 & 0.010 \\
\hline $\mathrm{Ce} 09$ & 24 & 24 & 1 & 5.50 & 0.64 & -0.008 \\
\hline Ce10 & 24 & 24 & 1 & 5.88 & 0.65 & -0.009 \\
\hline Ce11 & 24 & 24 & 1 & 4.88 & 0.62 & 0.031 \\
\hline Ce12 & 24 & 24 & 1 & 5.75 & 0.65 & 0.004 \\
\hline
\end{tabular}

a Field population from region Brittany (Br01-Br17) and from region Centre (Ce01-Ce12), geographically localized in Fig 1.

\section{Linkage disequilibrium}

Seventeen populations showed random association of all alleles at all loci. Linkage disequilibrium among alleles was not significant in 801 of 812 pair-wise comparisons (98.6\%). The index of multilocus linkage disequilibrium $r_{d}$ was low $\left(\left|r_{d}\right|<0.041\right)$ and not significant, and the null hypothesis of random mating was not rejected for all field populations (Table 3 ). When the complete data set was analysed as a single population, none of the pair-wise comparisons showed evidence of significant linkage disequilibrium.

\section{Genetic diversity among populations}

Hierarchical AMOVA revealed that ca. $97 \%$ of the genetic variability was distributed within populations, compared to only $2.56 \%$ among populations within a region, and $0.06 \%$ among regions. None of these three factors contributed significantly to total molecular variance $(P>0.05)$. Similarly, none of the pair-wise comparisons revealed significant population differentiation among populations $(\theta=-0.02$ to $0.05 ; P>0.05)$, with an average $F_{\text {st }}$ value of $0.003( \pm 0.004) . F_{\text {st }}$ maximal value $(0.05)$ was reached for the comparison between field populations $\mathrm{Ce} 08$ and $\mathrm{Br} 10$, two field populations from the two distinct regions sampled, separated by one of the farthest distance in the overall sampling $(318 \mathrm{~km}$; Fig 1). Nonetheless, there was no significant correlation between logarithmic geographic distance and genetic distance $F_{\mathrm{ST}} /\left(1-F_{\mathrm{ST}}\right)$, neither among all populations, nor within regions. Among all populations, the maximum distance between two populations was $364.2 \mathrm{~km}$; the linear regression between logarithmic geographic distance and pair-wise genetic distance was $y=1.13 \times 10^{-4} x+0.0015\left(r^{2}=1.7 \times 10^{-4} ; P=0.35\right)$ (Fig 2A). Among populations from Region Brittany, the maximum distance between two populations was $99.6 \mathrm{~km}$; the linear regression between logarithmic 
geographic distance and pairwise $F_{\mathrm{ST}} /\left(1-F_{\mathrm{ST}}\right)$ was $y=-1.5 \times 10^{-3} x+0.018\left(r^{2}=0.016 ; P=0.88\right)($ Fig $2 \mathrm{~B})$. Among populations from Region Centre, the maximum distance between two populations was $122.2 \mathrm{~km}$; the regression is $y=3.4 \times 10^{-4} x+2.53 \times 10^{-5}\left(r^{2}=1.5 \times 10^{-3} ; P=0.38\right)($ Fig $2 \mathrm{C})$.

Fig 2. Genetic differentiation among Leptosphaeria maculans populations. Multilocus estimates ( $\theta)$ of genetic differentiation $\mathrm{F}_{s t}$ expressed as $\mathrm{F}_{S T} /\left(1-\mathrm{F}_{S T}\right)$ are plotted against logarithm of geographic distance $(\mathrm{km})$ for $(A)$ each pair of L. maculans field populations (maximum distance between two populations is $364.2 \mathrm{~km}$; the regression is $\left.\mathrm{y}=1.13 \times 10^{-4} \mathrm{x}+0.0015 ; \mathrm{r}^{2}=1.7 \times 10^{-4} ; \mathrm{P}=0.35\right),(B)$ each pair of $\mathrm{L}$. maculans field populations from region Brittany (maximum distance between two populations is $99.6 \mathrm{~km}$; the regression is $\left.\mathrm{y}=-1.5 \times 10^{-3} \mathrm{x}+0.018 ; \mathrm{r}^{2}=0.016 ; \mathrm{P}=0.88\right)$, and $(C)$ each pair of $\mathrm{L}$. maculans field populations from region Centre (maximum distance between two populations is $122.2 \mathrm{~km}$; the regression is $\left.\mathrm{y}=3.4 \times 10^{-4} \mathrm{x}+2.53 \times 10^{-5} ; \mathrm{r}^{2}=1.5 \times 10^{-3} ; \mathrm{P}=0.38\right) . \mathrm{F}_{\text {st }}$ was estimated according to Weir \& Cockerham (1984).
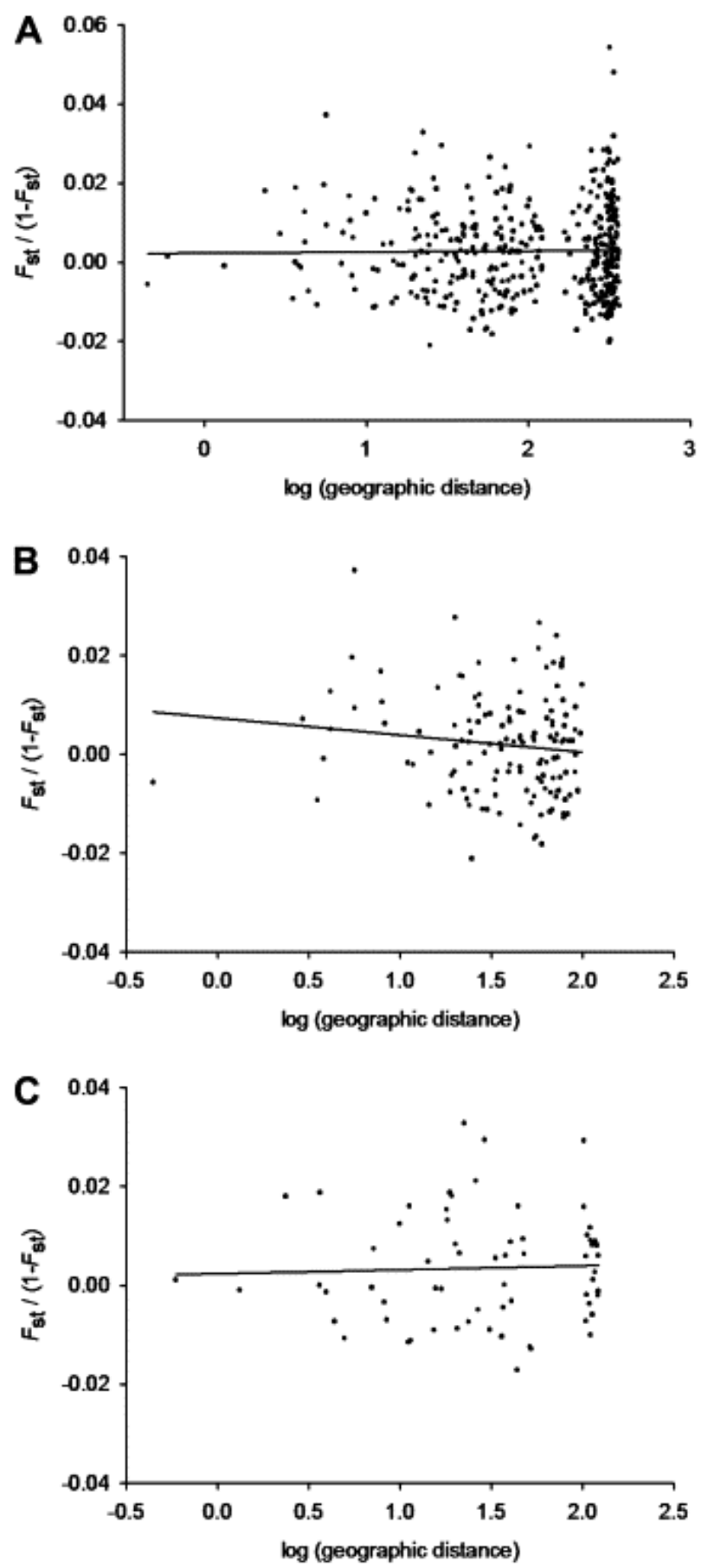
Effective population size fluctuations

Comparisons between observed and expected gene diversity revealed significant gene diversity excess for 20 of 29 populations, under TPM (Wilcoxon sign-rank test, $P<0.05$; Table 4$)$ and IAM $(P<0.05)$. Conversely, under SMM, none of the populations displayed significant gene diversity excess $(P>0.05)$. For the three models, no differences were found between regions.

Table 4. Probability for an excess in observed gene diversity $\left(\mathrm{H}_{\text {obs }}\right)$ compared to that expected under mutationdrift equilibrium, in each field population, tested with Wilcoxon sign-rank test, under three models: the IAM, the TPM, with $70 \%$ of alleles attributed to SMM and the SMM. P-values after 1000 simulation replicates are presented.

\begin{tabular}{|c|c|c|c|}
\hline \multirow{3}{*}{ Population } & \multicolumn{3}{|c|}{ Wilcoxon sign-rank test } \\
\hline & \multicolumn{3}{|c|}{ Probability for $\mathrm{H}_{\mathrm{obs}}$ excess (P-values) } \\
\hline & IAM & TPM & SMM \\
\hline $\mathrm{Br} 01$ & 0.014 & 0.098 & 0.629 \\
\hline $\mathrm{Br} 02$ & 0.010 & 0.037 & 0.371 \\
\hline $\mathrm{BrO3}$ & 0.037 & 0.230 & 0.844 \\
\hline $\mathrm{Br} 04$ & 0.010 & 0.156 & 0.320 \\
\hline $\mathrm{Br} 05$ & 0.004 & 0.008 & 0.234 \\
\hline Bro6 & 0.004 & 0.012 & 0.406 \\
\hline $\mathrm{BrO} 7$ & 0.004 & 0.014 & 0.156 \\
\hline Bro8 & 0.010 & 0.098 & 0.527 \\
\hline Bro9 & 0.010 & 0.037 & 0.422 \\
\hline $\mathrm{Br} 10$ & 0.004 & 0.004 & 0.289 \\
\hline $\mathrm{Bn} 11$ & 0.010 & 0.098 & 0.629 \\
\hline $\mathrm{Br} 12$ & 0.004 & 0.004 & 0.148 \\
\hline $\mathrm{Br} 13$ & 0.020 & 0.037 & 0.770 \\
\hline $\mathrm{Br} 14$ & 0.004 & 0.020 & 0.594 \\
\hline $\mathrm{Br} 15$ & 0.010 & 0.037 & 0.578 \\
\hline $\mathrm{Br} 16$ & 0.004 & 0.008 & 0.148 \\
\hline Br17 & 0.006 & 0.014 & 0.191 \\
\hline $\mathrm{Ce} 01$ & 0.004 & 0.027 & 0.098 \\
\hline $\mathrm{Ce} 02$ & 0.014 & 0.273 & 0.680 \\
\hline $\mathrm{Ce} 03$ & 0.008 & 0.039 & 0.406 \\
\hline $\mathrm{Ce} 04$ & 0.014 & 0.098 & 0.770 \\
\hline $\mathrm{Ce} 05$ & 0.004 & 0.039 & 0.594 \\
\hline $\mathrm{Ce} 06$ & 0.014 & 0.098 & 0.527 \\
\hline $\mathrm{Ce} 07$ & 0.010 & 0.027 & 0.473 \\
\hline $\mathrm{Ce} 08$ & 0.039 & 0.234 & 0.711 \\
\hline $\mathrm{Ce} 09$ & 0.004 & 0.020 & 0.406 \\
\hline Ce10 & 0.004 & 0.020 & 0.766 \\
\hline Ce11 & 0.004 & 0.008 & 0.289 \\
\hline Ce12 & 0.004 & 0.008 & 0.148 \\
\hline
\end{tabular}

\section{Discussion}

In characterizing the genetic structure of Leptosphaeria maculans populations in France, we intended to demonstrate that, in the case of this wind-dispersed phytopathogenic fungus, the scale of spore dispersal could be obtained from the theoretical migration model IBD. Despite the fact that our sampling scheme was based on a priori knowledge of spore dispersal, however, we did not detect a significant IBD pattern among populations. We will discuss how deviations from model assumptions occurring in populations, including departure from genetic equilibrium or gene flow higher than previously assumed, are likely to explain the inapplicability of the IBD model at the spatial scale studied.

The detection of IBD pattern strongly depends on the spatial scale studied, as the studied area should match the spatial scale at which gene dispersal occurs (Rousset 1997) and sampling at larger distances leads to an overestimation of demographic parameters (Leblois et al. 2003). Our sampling scheme was designed assuming that migration was due to ascospore dispersal over a few hundred metres, distances estimated from 
spore (Salam et al. 2001) and disease (Marcroft et al. 2004) gradients. As both methods are known to be inaccurate at large distances, i.e. over several kilometres (McCartney et al. 2006), it is possible that our sampling scale was too small, and that we underestimated ascospore dispersal. Our findings suggest that ascospore dispersal occurs at distances greater than several hundred metres. Undetected by direct methods, widespread spore dispersal at continental scale by atmospheric turbulence could occur for this fungus. Such long-distance dispersal events are known to be the main cause of the world-wide spread of plant diseases (Brown \& Hovmøller 2002). But assuming that these events have a low-frequency compared to local dispersal, based on reduced fungal spore viability under atmospheric conditions (Rotem et al. 1985), an IBD pattern should be detectable at the studied regional spatial scales.

Alternatively, it is possible that human transport of infected seeds is responsible for long-distance dispersal of L. maculans (Hall et al. 1996). Long-distance dispersal via human transport and, thus, high migration rates that reduce genetic differentiation between populations (Slatkin 1987), were suggested to explain the world-wide spread of other plant pathogens, such as the banana black leaf streak fungus Mycosphaerella fijiensis (Rivas et al. 2004), the wheat leaf blotch fungus Mycosphaerella graminicola (Linde et al. 2002), and the poplar rust fungus Melampsora larici-populina (Barrès et al. 2008). Nonetheless, long distance human-mediated transport of infected plant material would have to be regular and intense to erase population differentiation, which is locally driven by genetic drift in the absence of selection. Further investigations of infected seed material are necessary to elucidate its effect on the spread of L. maculans.

The absence of demographic equilibrium in the studied populations may have prevented the detection of IBD patterns, though empirical data showed that demographic estimates through the method used were robust to population density changes that occur within just a few generations (Leblois et al. 2004). In Region Brittany, oilseed rape acreage increased from 0 ha in 1983 to ca. 50000 ha in 2007 (Agreste 2008), yet a matching increase in effective population sizes was not detected in this region. As the test implemented in the BOTTLENECK software only allows the detection of recent size fluctuations, pathogen spread in Brittany, which possibly dates back from about 25 generations ago assuming one sexual cycle per season, may be too ancient for detection. In Region Centre, where oilseed rape has been intensively grown for more than $60 \mathrm{y}$, we might expect that coevolving L. maculans populations have reached demographic equilibrium. Nonetheless, annual, recurrent bottlenecks could hinder the detection of IBD patterns. For annual crop pathogens, this decrease in effective population size is expected when host plant material available for pathogen development dramatically decreases between growing seasons (Burdon 1993). However, the high levels of within-population genetic diversity revealed in this study, concordant with previous studies (Mahuku et al., 1997, Barrins et al., 2004, Gout et al., 2006, Hayden et al., 2007), do not support recent or recurrent bottlenecks. Furthermore, with SMM, considered the most conservative mutation model in the test conducted (i.e. the null hypothesis of no population size fluctuation is rejected only when a strong bottleneck signal is detected; Cornuet \& Luikart 1996), none of the populations showed significant recent changes in size. Multiple sampling dates and years are necessary to characterize the genetic diversity of L. maculans populations and to further examine their local and temporal demography.

The absence of both bottleneck signatures and significant spatial genetic structure among French populations of $L$. maculans suggest that these populations do not undergo strong loss of genetic diversity through genetic drift during the saprophytic stage on oilseed rape stubble. Instead, high proportion of genetic diversity distributed within-population (>97\%) suggests that the examined populations have large effective population sizes. Large effective population sizes reduce genetic differentiation among populations (Criscione et al. 2005) and hence limit the chance to detect IBD patterns. The substantial quantities of stubble that is not buried, but is instead left on the soil surface (Lydia Bousset, personal observation), can explain the maintenance of large effective population size in L. maculans.

The absence of linkage disequilibrium and the uniform distribution of mating types in all populations (data not shown) confirm the significance of sexual reproduction in the life-cycle of $L$. maculans, and are consistent with previous research identifying ascospores, and not conidia (i.e. spores resulting from asexual multiplication), as the main source of inoculum to initiate epidemics (Fitt et al. 2006). Nonetheless, three repeated haplotypes were detected in the same field and were unlikely to originate from distinct sexual reproduction events. These findings provide indirect evidence for the spread of isolates through splashdispersal of conidia in field conditions, hence supporting the involvement of conidia in the epidemiology of 
phoma stem canker on oilseed rape (Travadon et al. 2007). In contrast, similar associations of alleles in repeated haplotypes detected in distant fields were likely the result of random mating. Overall, genetic diversity indices estimated in all field populations are in agreement with the hypothesis that, in France, populations of L. maculans operate as one panmictic population.

As discussed in this study, the absence of IBD patterns in a wind-dispersed, plant-pathogenic fungus may not be only due to dispersal of spores or infected plants across large geographic distances. Instead, a focus on the inter-generation evolution of local genetic diversity may reveal the contribution of large effective population sizes and the absence of demographic equilibrium as factors that mask IBD patterns. Buffering the effects of genetic drift, the effective population size has a large influence on overall levels of genetic diversity (Criscione et al. 2005). For plant-pathogenic fungi not experiencing strong effects of genetic drift during their life-cycle, either because of constant host availability (i.e. perennial hosts), or because of their ability to survive saprophytically between host growing seasons, or due to their ability to infect multiple hosts, and thus to survive independently of one single host persistence, high levels of within-population genetic diversity and low levels of among-population differentiation are expected. In these cases the IBD model does not seem appropriate to infer dispersal distances.

Large effective population sizes, high dispersal rates and random mating confer a high evolutionary potential to L. maculans (McDonald \& Linde 2002), and such characteristics are consistent with its rapid adaptation to major resistance genes (Sprague et al. 2006). Since effective population sizes affect local adaptive potential to evolve in response to host resistance, it is necessary to reduce effective population size in L. maculans populations. Accordingly, management practices between growing seasons, especially burial of the oilseed rape stubble from which the pathogen fruits, is recommended (Aubertot et al. 2006). Disease control strategies aiming at either the prevention of virulent spore dispersal from resistant crops to new resistant crops through spatial cultivar deployment, or at the reduction of sexual reproduction via stubble management, are essential to preserve the efficacy of the few available specific resistance genes against $L$. maculans in B. napus.

\section{Acknowledgements}

This work was supported by «ANR- Agence Nationale de la Recherche - The French National Research Agency » program « Agriculture et Développement Durable », grant «ANR-05-PADD-05, CEDRE », and by a grant from INRA (Divisions Santé des Plantes et Environnement and Écologie des Forêts, Prairies et milieux Aquatiques: Projet Épidémiologie et dynamique des populations). A. Stachowiak was funded by Marie-Curie FellowshipHPMT-CT-2001-00395 'FUNGENE'. We thank K. Baumgartner (USDA-ARS, Davis, CA) for review of this manuscript.

\section{References}

Agapow and Burt, 2001 P.-M. Agapow, A. Burt Indices of multilocus linkage disequilibrium Molecular Ecology Notes, 1 (2001), pp. 101-102

Agreste, 2008 Tableaux de l'agriculture bretonne Direction régionale de l'agriculture et de la forêt de Bretagne (2008), pp. 63-65

Google Scholar

Arnaud-Haond and Belkhir, 2007 S. Arnaud-Haond, K. Belkhir GENCLONE: a computer program to analyse genotypic data, test for clonality and describe spatial clonal organization Molecular Ecology Notes, 7 (2007), pp. $15-17$

Attard et al., 2002 A. Attard, L. Gout, M. Gourgues, M.L. Kuhn, J. Schmit, S. Laroche, D. Ansan-Melayah, A. Billault, L. Cattolico, M.H. Balesdent, T. Rouxel Analysis of molecular markers genetically linked to the Leptosphaeria maculans avirulence gene AvrLml in field populations indicates a highly conserved event leading to virulence on Rlml genotypes Molecular Plant-Microbe Interactions, 15 (2002), pp. 672-682

Aubertot et al., 2006 J.N. Aubertot, J.S. West, L. Bousset-Vaslin, M.U. Salam, M.J. Barbetti, A.J. Diggle Improved resistance management for durable disease control: a case study of phoma stem canker of oilseed rape (Brassica napus) European Journal of Plant Pathology, 114 (2006), pp. 91-106

Aylor and Irwin, 1999 D.E. Aylor, M.E. Irwin Aerial dispersal of pests and pathogens: implications for integrated pest management Agricultural and Forest Meteorology, 97 (1999), pp. 233-234 
Balesdent et al., 2001 M.H. Balesdent, A. Attard, D. Ansan-Melayah, R. Delourme, M. Renard, T. Rouxel Genetic control and host range of avirulence toward Brassica napus cultivars Quinta and Jet Neuf in Leptosphaeria maculans Phytopathology, 91 (2001), pp. 70-76

Barrès et al., 2008 B. Barrès, F. Halkett, C. Dutech, A. Andrieux, J. Pinon, P. Frey Genetic structure of the poplar rust fungus Melampsora larici-populina: evidence for isolation by distance in Europe and recent founder effects overseas Infection Genetics and Evolution, 8 (2008), pp. 577-587

Barrins et al., 2004 J.M. Barrins, P.K. Ades, P.A. Salisbury, B.J. Howlett Genetic diversity of Australian isolates of Leptosphaeria maculans, the fungus that causes blackleg of canola (Brassica napus) Australasian Plant Pathology, 33 (2004), pp. 529-536

Benson, 1999 G. Benson Tandem repeats finder: a program to analyze DNA sequences Nucleic Acids Research, 27 (1999), pp. 573-580

Brown and Hovmøller, 2002 J.K. Brown, M.S. Hovmøller Aerial dispersal of pathogens on the global and continental scales and its impact on plant disease Science, 297 (2002), pp. 537-541

Burdon, 1993 J.J. Burdon Genetic variation in pathogen populations and its implications for adaptation to host resistance T.H. Jacobs, J.E. Parlevliet (Eds.), Durability of Disease Resistance, Kluwer Academic Publishers (1993), pp. 41-56

Chèvre et al., 2008 A.M. Chèvre, H. Brun, F. Eber, J.C. Letanneur, P. Vallee, M. Ermel, I. Glais, H. Li, K. Sivasithamparam, M.J. Barbetti Stabilization of resistance to Leptosphaeria maculans in Brassica napus $-B$. juncea recombinant lines and its introgression into spring-type Brassica napus Plant Disease, 92 (2008), pp. $1208-1214$

Cornuet and Luikart, 1996 J.M. Cornuet, G. Luikart Description and power analysis of two tests for detecting recent population bottlenecks from allele frequency data Genetics, 144 (1996), pp. 2001-2014

Criscione et al., 2005 C.D. Criscione, R. Poulin, M.S. Blouin Molecular ecology of parasites: elucidating ecological and microevolutionary processes Molecular Ecology, 14 (2005), pp. 2247-2257

Dorken and Eckert, 2001 M.E. Dorken, C.G. Eckert Severely reduced sexual reproduction in northern populations of a clonal plant, Decodon verticillatus (Lythraceae) Journal of Ecology, 89 (2001), pp. 339-350

Eckert et al., 2005 M. Eckert, L. Gout, T. Rouxel, F. Blaise, M. Jedryczka, B. Fitt, M.H. Balesdent Identification and characterization of polymorphic minisatellites in the phytopathogenic ascomycete Leptosphaeria maculans Current Genetics, 47 (2005), pp. 37-48

Excoffier et al., 2005 L. Excoffier, G. Laval, S. Schneider Arlequin (version 3.0): an integrated software package for population genetics data analysis Evolutionary Bioinformatics, 1 (2005), pp. 47-50

Fitt et al., 2006 B.D.L. Fitt, H. Brun, M.J. Barbetti, S.R. Rimmer World-wide importance of phoma stem canker (Leptosphaeria maculans and L. biglobosa) on oilseed rape (Brassica napus) European Journal of Plant Pathology, 114 (2006), pp. 3-15

Gall et al., 1994 C. Gall, M.H. Balesdent, P. Robin, T. Rouxel Tetrad analysis of acid phosphatase, soluble protein patterns, and mating type in Leptosphaeria maculans Phytopathology, 84 (1994), pp. 1299-1305

Gandon et al., 1996 S. Gandon, Y. Capowiez, Y. Dubois, Y. Michalakis, I. Olivieri Local adaptation and gene-forgene coevolution in a metapopulation model Proceedings of the Royal Society of London Series B: Biological Sciences, 263 (1996), pp. 1003-1009

Goudet, 1995 J. Goudet FSTAT (Version 1.2): a computer program to calculate F-statistics Journal of Heredity, 86 (1995), pp. 485-486

Gout et al., 2006 L. Gout, M. Eckert, T. Rouxel, M.H. Balesdent Genetic variability and distribution of mating type alleles in field populations of Leptosphaeria maculans from France Applied and Environmental Microbiology, 72 (2006), pp. 185-191

Gregory, 1973 P.H. Gregory Microbiology of the Atmosphere Leonard Hill, Aylesbury (1973)

Hall et al., 1996 R. Hall, J.L. Chigogora, L.G. Phillips Role of seedborne inoculum of Leptosphaeria maculans in development of blackleg on oilseed rape Canadian Journal of Plant Pathology, 18 (1996), pp. 35-42

Hardy et al., 2006 O.J. Hardy, L. Maggia, E. Bandou, P. Breyne, H. Caron, M.H. Chevallier, A. Doligez, C. Dutech, A. Kremer, C. Latouche-Halle, V. Troispoux, V. Veron, B. Degen Fine-scale genetic structure and gene dispersal inferences in 10 Neotropical tree species Molecular Ecology, 15 (2006), pp. 559-571

Hardy and Vekemans, 2002 O.J. Hardy, X. Vekemans Spagedi: a versatile computer program to analyse spatial genetic structure at the individual or population levels Molecular Ecology Notes, 2 (2002), pp. 618-620 
Hayden et al., 2007 H.L. Hayden, A.J. Cozijnsen, B. Howlett Microsatellite and minisatellite analysis of Leptosphaeria maculans in Australia reveals regional genetic differentiation Phytopathology, 97 (2007), pp. 879-887

Kaltz and Shykoff, 1998 O. Kaltz, J.A. Shykoff Local adaptation in host-parasite systems Heredity, 81 (1998), pp. 361-370

Leblois et al., 2003 R. Leblois, A. Estoup, F. Rousset Influence of mutational and sampling factors on the estimation of demographic parameters in a "Continuous" population under isolation by distance Molecular Biology and Evolution, 20 (2003), pp. 491-502

Leblois et al., 2004 R. Leblois, F. Rousset, A. Estoup Influence of spatial and temporal heterogeneities on the estimation of demographic parameters in a continuous population using individual microsatellite data Genetics, 166 (2004), pp. 1081-1092

Linde et al., 2002 C.C. Linde, J. Zhan, B.A. McDonald Population structure of Mycosphaerella graminicola: from lesions to continents Phytopathology, 92 (2002), pp. 946-955

Luikart et al., 1997 G. Luikart, J. Painter, R.H. Crozier, M. Westerman, W.B. Sherwin Characterization of microsatellite loci in the endangered long-footed potoroo Potorous longipes Molecular Ecology, 6 (1997), pp. 497-498

Mahuku et al., 1997 G.S. Mahuku, P.H. Goodwin, R. Hall, T. Hsiang Variability in the highly virulent type of Leptosphaeria maculans within and between oilseed rape fields Canadian Journal of Botany, 75 (1997), pp. 1485-1492

Marcroft et al., 2004 S.J. Marcroft, S.J. Sprague, S.J. Plymer, P.A. Salisbury, B.J. Howlett Crop isolation, not extended rotation length, reduces blackleg (Leptosphaeria maculans) severity of canola (Brassica napus) in south-eastern Australia Australian Journal of Experimental Agriculture, 44 (2004), pp. 601-606

McCartney et al., 2006 H.A. McCartney, B.D.L. Fitt, J. West Dispersal of foliar plant pathogens: mechanisms, gradients and spatial patterns B.M. Cooke, D. Gareth Jones, B. Kaye (Eds.), The Epidemiology of Plant Diseases, Springer, Dordrecht (2006), pp. 159-192

McDonald and Linde, 2002 B.A. McDonald, C. Linde Pathogen population genetics, evolutionary potential, and durable resistance Annual Review of Phytopathology, 40 (2002), pp. 349-379

McGee, 1977 D.C. McGee Black leg (Leptosphaeria maculans (Desm.) Ces. et de Not.) of rapeseed in Victoria: sources of infection and relationships between inoculum, environmental factors and disease severity Australian Journal of Agricultural Research, 28 (1977), pp. 53-62

Mendes-Pereira et al., 2003 E. Mendes-Pereira, M.H. Balesdent, H. Brun, T. Rouxel Molecular phylogeny of the Leptosphaeria maculans - L. biglobosa species complex Mycological Research, 107 (2003), pp. 1287-1304

Nei, 1987 M. Nei Molecular Evolutionary Genetics Columbia University Press, New York (1987)

Piry et al., 1999 S. Piry, G. Luikart, J.M. Cornuet Computer note. BOTTLENECK: a computer program for detecting recent reductions in the effective size using allele frequency data Journal of Heredity, 90 (1999), pp. $502-503$

Prolea, 2008 Prolea, 2008. De la production à la consommation - Statistiques des oléagineux et protéagineux, huiles et protéines végétales 2007-2008.

Purwantara et al., 2000 A. Purwantara, J.M. Barrins, A.J. Cozijnsen, P.K. Ades, B.J. Howlett Genetic diversity of isolates of the Leptosphaeria maculans species complex from Australia, Europe and North America using amplified length polymorphism analysis Mycological Research, 104 (2000), pp. 772-781

Raymond and Rousset, 1995 M. Raymond, F. Rousset GENEPOP (Version 1.2): population genetics software for exact tests and ecumenicism Journal of Heredity, 86 (1995), pp. 248-249

Rienzo et al., 1994 A.D. Rienzo, A.C. Peterson, J.C. Garza, A.M. Valdes, M. Slatkin, N.B. Freimer Mutational processes of simple-sequence repeat loci in human populations Proceedings of the National Academy of Sciences, 91 (1994), pp. 3166-3170

Rivas et al., 2004 G.-G. Rivas, M.-F. Zapater, C. Abadie, J. Carlier Founder effects and stochastic dispersal at the continental scale of the fungal pathogen of bananas Mycosphaerella fijiensis Molecular Ecology, 13 (2004), pp. 471-482

Rotem et al., 1985 J. Rotem, B. Wooding, D.E. Aylor The role of solar-radiation, especially ultraviolet, in the mortality of fungal spores Phytopathology, 75 (1985), pp. 510-514 
Rousset, 1997 F. Rousset Genetic differentiation and estimation of gene flow from F-statistics under isolation by distance Genetics, 145 (1997), pp. 1219-1228

Rousset, 2001 F. Rousset Inferences from spatial population genetics D.A. Balding, M. Bishop, C. Cannings (Eds.), Handbook of Statistical Genetics, John Wiley \& Sons, Chicester, UK (2001), pp. 239-265

Salam et al., 2001 M.U. Salam, J. Galloway, R. Khangura, A.J. Diggle, W.J. MacLeod, M.J. Barbetti Spatial spread of blackleg in canola - a regional scale simulation model S.J. Marcroft (Ed.), Proceedings of the 12th Australian Research Assembly on Brassicas, Geelong, Victoria (October 2-5, 2001), pp. 101-105

Slatkin, 1987 M. Slatkin Gene flow and the geographical structure of natural populations Science, 236 (1987), pp. 787-792

Sprague et al., 2006 S.J. Sprague, M.H. Balesdent, H. Brun, H.L. Hayden, S.J. Marcroft, X. Pinochet, T. Rouxel, B. Howlett Major gene resistance in Brassica napus (oilseed rape) is overcome by changes in virulence of populations of Leptosphaeria maculans in France and Australia European Journal of Plant Pathology, 114 (2006), pp. 33-40

Travadon et al., 2007 R. Travadon, L. Bousset, S. Saint-Jean, H. Brun, I. Sache Splash dispersal of Leptosphaeria maculans pycnidiospores and the spread of blackleg on oilseed rape Plant Pathology, 56 (2007), pp. 595-603

Weir and Cockerham, 1984 B.S. Weir, C.C. Cockerham Estimating F-statistics for the analysis of population structure Evolution, 38 (1984), pp. 1358-1370

Whitlock and McCauley, 1999 M.C. Whitlock, D.E. McCauley Indirect measures of gene flow and migration: F-ST not equal 1/(4Nm+1) Heredity, 82 (1999), pp. 117-125

Wright, 1943 S. Wright Isolation by distance Genetics, 2 (1943), pp. 114-138

Zaffarano et al., 2006 P.L. Zaffarano, B.A. McDonald, M. Zala, C.C. Linde Global hierarchical gene diversity analysis suggests the Fertile Crescent is not the center of origin of the barley scald pathogen Rhynchosporium secalis Phytopathology, 96 (2006), pp. 941-950 